\title{
PENERAPAN KONSEP CROSSDOCKING UNTUK MENURUNKAN PERSEDIAAN DI PT. COCA COLA DISTRIBUSI MALANG
}

\author{
Mubin $^{*}$
}

\begin{abstract}
This Final duty produce design model distribution system for the finished of problems of product distribution stream. Method which used in system model is method of Crossdocking. Crossdocking used as by method to schedule delivery of product. There is two step scheduling of delivery, first of scheduling of delivery of factory - Sales Center and both scheduling of shipping of Sales Center - outlet.

Crossdocking represent distribution method as a mean to minimize of is expense of supply, Crossdocking applied by functioned Sales Centar as facility of Crossdock, where at its distribution process of product sent from factory to outlet pass Sales Center without passing inventory storage process. Scheduling of first phase cover amount, time, target of delivery, and used vehicle. By the end of this system device done by calculation of safety stock as anticipation to avoid stock out to demand of final consumer.

Of device model this Crossdocking can be yielded decrease of inventory level in Sales Center, and decrease of transportation cost from factory to Sales Center.
\end{abstract}

Keyword : Crosdocking, Supply, Safety Stock.

\section{A. PENDAHULUAN}

PT. Coca-Cola Bottling Indonesia merupakan perusahaan minuman internasional yang bermarkas besar di Australia, yang menangani seluruh kegiatan operasional dan distribusi produk coca-cola diseluruh Indonesia, perusahaan ini membawahi 12 pabrik yang tersebar di pulau jawa, Sumatra, kalimantan, sulawesi. Produk-produk yang dihasilkan oleh pabrik-pabrik tersebut antara lain: coca-cola, sprite dan fanta, baik dalam kemasan botol (RGB), botol palstik (PET) maupun kaleng (CAN). Di PT. Coca-Cola Bottling Indonesia pola distribusi yang diterapkan yaitu produk dari factory dikirim ke sales center kemudian baru dikirim ke outlet. Berdasarkan observasi yang telah dilakukan pada sales center distribusi Malang, penentuan kebijakan peletakan inventori yang ada dilakukan secara terpusat pada Factory. Sehingga sales center tidak memiliki otoritas ataupun wewenang untuk memesan produk yang dibutuhkan serta merespon setiap perubahan (dinamika) yang terjadi pada pasar secara langsung. Sales center hanya mempunyai wewenang untuk mengirim data penjualan setiap harinya ke pihak Factory, dan pihak Factory yang menentukan berapa banyak serta kapan barang akan dikirim untuk sales center. Maka dalam skenario ini sering terjadi antara kapasitas pengiriman produk dari factory ke sales center dengan kapasitas permintaan aktual yang ada tidak sesuai hal ini menyebabkan banyaknya persediaan di sales center maka untuk mendapatkan penyelesaian dari masalah diatas diusulkan sebuah sistem distribusi yang diharapkan akan tercapai suatu keselarasan antara pengiriman produk dari factory ke sales center dan dari sales center ke outlet.

Konsep crossdocking adalah salah satu startegi distribusi yang pada penerapannya

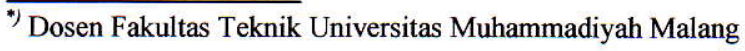


pengiriman produk dari factory ke sales center dan dari sales center ke outlet.

Konsep crossdocking adalah salah satu startegi distribusi yang pada penerapannya ditujukan untuk melancarkan aliran produk dari pabrik hingga ka ritel. Crossdocking adalah suatu konsep dimana

Warehouse berfungsi sebagai tempat koordinasi, tidak lagi sebagai tempat penyimpanan persediaan (Levi,2000). Pada sistem distribusi crossdocking ini, produk dari pabrik yang tiba di warehouse, dipindahkan ke alat pengiriman yang ada di warehouse dan dikirim ke ritel/distributor sesegera mungkin. Sistem ini meminimasi inventory cost.

Kerja sama antar pabrik dan warehouse yang ditawarkan oleh metode crossdocking berguna untuk mengurangi jumlah inventori, menambah kecepatan pergantian inventori, mengurangi leadtime pengiriman. Yang perlu menjadi perhatian adalah jangan sampai terjadi pasar kekurangan produk, karena akan menyebabkan lost sale bagi perusahaan dan tidak boleh terjadi even dimana distributor/outlet mengalami stockout karena keterlambatan pengiriman. Oleh karena itu diperlukan suatu sistem safety stock untuk mengantisipasi agar tidak terjadi lost sales.

\section{B. LANDASAN TEORI}

\section{Strategi Distribusi}

Distribusi merupakan elemen yang penting dalam logistic. Dalam pemasaran produknya, suatu perusahaan harus memiliki strategi khusus dalam menyiasati persaingan dengan produsenprodusen produk yang sama. Dalam menentukan penerapan sistem distribusinya, suatu perusahaan amat tergantung pada kebijaksanaan manajemennya. Namun secara umum tipe-tipe strategi distribusi dapat dikelompokkan menjadi beberapa tipe. Tipe-tipe strategi distribusi ada 3 (Levi,2000, 112)

\section{$>$ Direct shipment}

Dalam strategi ini, produk dikirim langsung dari supplier ke ritel tanpa melalui pusat distribusi. Dalam strategi ini, diperlukan kendaraan dalam jumlah yang banyak. Tidak terdapat penyimpanan persediaan pada warehouse, karena warehouse atau pusat distribusi tidak ada.

\section{$>$ Warehousing}

Strategi ini merupakan strategi klasik dimana warehouse menyadiakan stok dan melayqni pelanggan sesuai permintaannya. Warehousing dapat didefinisikan sebagai bagian logistic yang mengatur masalah penyimpanan produk pada produksi, konsumsi dan diantara produksi dan konsumsi. Aktivitas warehousing juga menyediakan informasi bagi pihak manajemen tentang status, kondisi, dan disposisi item produk yang disimpan. Dalam pelaksanaannya warehouse adalah istilah yang lebih umum dibandingkan dengan distribution centre (DC).

Keputusan operasional, dimana :

- Keputusan strategis berhubungan dengan pengalokasian sumber daya logistik dalam batas waktu tertentu secara konsisten dan juga menunjang penentuan kebijaksanaan dalam aktivitas-aktivitas perusahaan yang lain. 
- Keputusan operasional berhubungan dengan kebijaksanaan mengenai pengelolaan dan pengendalian dari performansi logistic, dan sifatnya rutin dalam jangka waktu satu tahun atau kurang.

\section{$>$ Crossdocking}

Pada strategi ini, produk didistribusikan secara terus-menerus dari supplier menuju warehouse kemudian ke konsumen. Tetapi produk berada di warehouse berkisar antara 10 hingga 15 jam, dan warehouse bukan berfungsi sebagai penumpukan persediaan.

\section{Crossdocking}

- Crossdocking merupakan salah satu teknik logistik yang relatife masih baru, yang digunakan pada pusat distribusi dan industri transportasi. Sistem ini berfungsi untuk mengkonsolidasikan antara produk-produk yang tiba di pusat distribusi untuk selanjutnya dikirim ke retailer dengan memperhatikan factor waktu dan beban muatan transporter.

Produk yang bagus untuk penerapan crossdocking adalah produk dengan permintaan yang tinggi dan variansi permintaannya rendah. Hal ini dikarenakan crossdocking sama seperti Just In Time Manufacturing, dapat berjalan pada variansi yang rendah dan terdapat jumlah yang cukup untuk memenuhi permintaan konsumen.

\section{METODE}

- Studi Pendahuluan

Dilakukannya studi pendahuluan ini adalah untuk mendapatkan informasi yang selengkap mungkin dari obyek sistem yang diteliti. Dalam studi pendahuluan ini, peneliti berusaha untuk mempelajari kondisi sebenarnya dari perusahaan terutama yang berkaitan dengan permasalahan distribusi produk.

- Studi Referensi

Pada tahap ini akan dipelajari teori-teori dan informasi yang berhubungan dengan pemecahan masalah yang dilakukan.

- Pengumpulan Data

Pengumpulan data pada penelitian ini didapat dengan tiga cara yaitu:

- Menggunakan data sekunder dari perusahaan

- Melakukan wawancara dengan karyawan di perusahaan

- Melakukan pengamatan secara langsung dan mengambil data yang diperlukan dari pengamatan tersebut

- Tahap Permodelan Sistem

Permodelan yang dibuat adalah permodelan untuk menyalesaikan penjadwalan pengiriman produk menurut penerapan metode crossdocking.

- Tahap Pengolahan Data

Selanjutnya dilakukan pengujian model pada tahap pengolahan data.

- Tahap Analisa dan Kesimpulan

Pada tahap ini, akan dilakukan interpretasi hasil dari pengolahan data pada model, yang selanjutnya dianalisa untuk dapat diambil kesimpulan-kesimpulan mengenai metode crossdocking yang diterapkan pada 
perusahaan dan penjadwalan pengiriman produk yang dilakukan.

\section{ANALISA}

\section{Penentuan Safety Stock}

Ketidakpastian jumlah dan waktu permintaan, lead time dan jumlah serta penyelesaian produksi merupakan problem yang sering terjadi. Ketidakpastian ini dapat menyebabkan kehabisan persediaan atau sebaliknya jumlah persediaan yang terlalu banyak. Maksimum tingkat persediaan dibawah distribusi normal untuk model FPQ adalah:

$$
\begin{aligned}
& S S=Z \sigma_{D} \sqrt{T+L} \\
& E=\bar{M}+S S \text { atau } E=\bar{D}(T+L)+S S
\end{aligned}
$$

Dimana :

$$
\begin{array}{ll}
\mathrm{SS} & =\text { safety stock } \\
E & =\text { maksimum tingkat persediaan (unit) } \\
\bar{M} & =\text { rata-rata permintaan selama order } \\
& \text { interval + lead time } \\
Z & =\text { standar deviasi normal } \\
\sigma_{D} & =\text { standar deviasi permintaan } \\
T & =\text { order interval } \\
\bar{D} & = \\
L & =\text { rata-rata permintaan (tahun) } \\
& \text { lead time }
\end{array}
$$

(Tersine, $1983: 212$ )

Untuk data yang tidak berdistribusi normal maka perhitungan safety stock menggunakan distribusi empiris. . Safety stock untuk data yang berdistribusi empiris adalah :

$$
\mathrm{SS}_{\mathrm{FOQ}}=\mathrm{d}_{\max }-\bar{d}
$$

Dimana :

$\mathrm{SS}=$ safety stock

$\mathrm{d}_{\max }=$ permintaan maksimal

$\bar{d}=$ permintaan rata-rata

( Teguh Baroto, $2002: 88$ )

Dari penghitungan safety stock dapat diketahui bahwa jumlah safety stock untuk road 1 sebesar 25 (dalam satuan krat). Untuk road 2 sampai road 21 jumlah safety stock dapat dilihat pada tabel 1 berikut :

\section{Tabel 1}

\section{Jumlah Safety stock}

\begin{tabular}{|c|c|}
\hline Wilayah/Road & $\begin{array}{c}\text { Safety Stock } \\
\text { (krat) }\end{array}$ \\
\hline Road 1 & 25 \\
\hline Road 2 & 30 \\
\hline Road 3 & 36 \\
\hline Road 4 & 32 \\
\hline Road 5 & 26 \\
\hline Road 6 & 30 \\
\hline Road 7 & 30 \\
\hline Road 8 & 29 \\
\hline Road 9 & 30 \\
\hline Road 10 & 25 \\
\hline Road 11 & 25 \\
\hline Road 12 & 31 \\
\hline Road 13 & 30 \\
\hline Road 14 & 25 \\
\hline Road 15 & 24 \\
\hline Road 16 & 27 \\
\hline Road 17 & 28 \\
\hline Road 18 & 20 \\
\hline Road 19 & 36 \\
\hline Road 20 & 27 \\
\hline Road 21 & 27 \\
\hline Jumlah & 593 \\
\hline
\end{tabular}

Hasil dari perhitungan tersebut adalah jumlah yang harus ada di sales center untuk mengantisipasi adanya fluktuasi penjualan. Jumlah persediaan yang harus ada di sales center dengan adanya system safety stock sebesar $\geq 593$ krat (satu krat berisi 24 botol).

\section{Persediaan}


Persediaan adalah sumber daya menganggur ( idle resource) yang menunggu proses lebih lanjut. Yang dimaksud dengan proses lebih lanjut tersebut adalah berupa kegiatan produksi pada sistem manufaktur, kegiatan pemasaran pada sistem distribusi ataupun kegiatan konsumsi pangan pada sistem rumah tangga (Arman Hakim Nasution, 2003, 103).

Persediaan produk di Sales Center malang selama ini sesuai dengan kebijakan perusahaan yaitu tiga kali penjualan/ tiga kali potensi, hal ini menyebabkan jumlah persediaan yang sangat besar di sales center, dengan jumlah persediaan yang besar maka biaya penyimpanan juga akan besar.

Biaya penyimpanan adalah biaya yang dikeluarkan karena adanya inventori atau persediaan yang berada di sales center. Biaya penyimpanan ini meliputi biaya investasi gedung, fasilitas penyimpanan seperti krat dan alat pemindahan, tenaga kerja yang menangani gudang. Secara sederhana besarnya biaya - biaya ini dapat dinyatakan sebagai fraksi biaya produk. Berdasarkan pihak manajemen perusahaan, besarnya biaya simpan adalah berkisar $20 \%$ dari harga produk/tahun dengan rincian sebagai berikut :

Biaya investasi gedung dan pemeliharaan: $5 \%$

Asuransi $: 3 \%$

Pajak $: 2.5 \%$

Investasi peralatan dan pemeliharaan: $5 \%$

Tenaga kerja langsung dan tak langsung $4.5 \%$

Harga produk/tahun sebesar Rp 1825,-

Besarnya biaya simpan produk/tahun adalah sebagai berikut:

Biaya simpan produk/tahun

$$
\begin{aligned}
& =20 \% \times \operatorname{Rp~1825,-} \\
& =\operatorname{Rp} 365,-
\end{aligned}
$$

Biaya simpan produk/hari

$$
\begin{aligned}
& =\operatorname{Rp} 365: 365 \text { hari } \\
& =\operatorname{Rp~1,-/hari~}
\end{aligned}
$$

Total biaya simpan yang diperlukan sesuai dengan perhitungan pada bab sebelumnya yaitu

Rp 1,-/produk/hari (Rp 1,-/botol/hari).

Jumlah persediaan di sales center malang selama satu bulan dapat dilihat pada tabel 2 berikut ini:

Tabel 2

Jumlah persediaan di Sales Center Malang bulan September 2004

\begin{tabular}{|c|c|c|c|c|c|c|}
\hline $\begin{array}{c}\text { Initial } \\
\text { Inventori }\end{array}$ & Tanggal & $\begin{array}{c}\text { JmI } \\
\text { pengiriman } \\
\text { dr pabrik }\end{array}$ & $\begin{array}{c}\text { JmI } \\
\text { pengiriman } \\
\text { Ke outlet }\end{array}$ & $\begin{array}{c}\text { Safety } \\
\text { stock }\end{array}$ & $\begin{array}{c}\text { Sediaan } \\
\text { Akhir di SC }\end{array}$ & Persediaan \\
\hline 9960 & 30 -Agt-04 & 3932 & 3473 & 10419 & 10419 & 250056 \\
\hline & $31-$ Agt-04 & 3461 & 3470 & 10410 & 10410 & 249840 \\
\hline & 1-Sep-04 & 3486 & 3474 & 10422 & 10422 & 250128 \\
\hline & 2-Sep-04 & 3438 & 3465 & 10395 & 10395 & 249480 \\
\hline & 3-Sep-04 & 3429 & 3456 & 10368 & 10368 & 248832 \\
\hline & 4-Sep-04 & 3440 & 3452 & 10356 & 10356 & 248544 \\
\hline & 6-Sep-04 & 3068 & 3356 & 10068 & 10068 & 241632 \\
\hline
\end{tabular}




\begin{tabular}{|c|c|c|c|c|c|c|}
\hline $\begin{array}{c}\text { Initial } \\
\text { Inventori }\end{array}$ & Tanggal & $\begin{array}{c}\text { Jml } \\
\text { pengiriman } \\
\text { dr pabrik }\end{array}$ & $\begin{array}{c}\text { JmI } \\
\text { pengiriman } \\
\text { Ke outlet }\end{array}$ & $\begin{array}{l}\text { Safety } \\
\text { stock }\end{array}$ & $\begin{array}{c}\text { Sediaan } \\
\text { Akhir di SC }\end{array}$ & $\begin{array}{c}\text { Biaya } \\
\text { Persediaan }\end{array}$ \\
\hline & 7-Sep-04 & 3344 & 3353 & 10059 & 10059 & 241416 \\
\hline & 8-Sep-04 & 3313 & 3343 & 10029 & 10029 & 240696 \\
\hline & 9-Sep-04 & 3311 & 3335 & 10005 & 10005 & 240120 \\
\hline & $10-$ Sep-04 & 3347 & 3338 & 10014 & 10014 & 240336 \\
\hline & 11-Sep-04 & 3366 & 3345 & 10035 & 10035 & 240840 \\
\hline & 14-Sep-04 & 3309 & 3336 & 10008 & 10008 & 240192 \\
\hline & 15 -Sep-04 & 3360 & 3342 & 10026 & 10026 & 240624 \\
\hline & 16-Sep-04 & 3370 & 3349 & 10047 & 10047 & 241128 \\
\hline & 17-Sep-04 & 3365 & 3353 & 10059 & 10059 & 241416 \\
\hline & 18-Sep-04 & 3421 & 3370 & 10110 & 10110 & 242640 \\
\hline & 20-Sep-04 & 3406 & 3379 & 10137 & 10137 & 243288 \\
\hline & 21-Sep-04 & 3339 & 3369 & 10107 & 10107 & 242568 \\
\hline & 22-Sep-04 & 3365 & 3368 & 10104 & 10104 & 242496 \\
\hline & 23-Sep-04 & 3440 & 3386 & 10158 & 10158 & 243792 \\
\hline & 24-Sep-04 & 3422 & 3395 & 10185 & 10185 & 244440 \\
\hline & 25 -Sep-04 & 3347 & 3383 & 10149 & 10149 & 243576 \\
\hline & 26-Sep-04 & 3211 & 3340 & 10020 & 10020 & 240480 \\
\hline & 28-Sep-04 & 3316 & 3334 & 10002 & 10002 & 240048 \\
\hline & 29-Sep-04 & 3346 & 3337 & 10011 & 10011 & 240264 \\
\hline & 30-Sep-04 & 3345 & 3339 & 10017 & 10017 & 240408 \\
\hline & 1-Okt-04 & 3347 & 3341 & 10023 & 10023 & 240552 \\
\hline & 2-Okt-04 & 3341 & 3341 & 10023 & 10023 & 240552 \\
\hline \multicolumn{6}{|c|}{ Sumber: Sales Center Wilayah Malang } & 7.050 .384 \\
\hline
\end{tabular}

Dari tabel 2 safety stock yang tersedia di Sales Center Malang sebesar tiga kali penjualan $(3 \mathrm{x}$ potensi) krat per hari. Pada saat produk dikirim dari pabrik ke Sales Center produk langsung dipindahkan ke gudang SC. Pada saat SC mengirim produk ke outlet produk diambil dari gudang SC ke kendaraan yang mengantar produk ke outlet. Sebelum diterapkan crossdocking, produk yang tiba di SC langsung dipindahkan ke gudang, hal ini disebabkan karena belum adanya penjadwalan kendaraan dari pabrik ke SC.

Pada penerapan crossdocking, produk yang tiba di Sales Center langsung dipindahkan ke kendaraan yang mengangkut produk ke outlet, sehingga diperlukan penjadwalan kapan produk harus dikirim ke SC, dan berapa jumlah produk yang harus dikirim.

Setelah dilakukannya perhitungan safety stock maka didapatkan safety stock yang ada di Sales Center Malang sebesar 593 krat. Jadi jumlah persediaan yang harus ada di $\mathrm{SC} \geq 593$ krat. Jumlah persediaan pada bulan Oktober 2004 di Sales Center Malang sebelum diterapkan crossdocking dapat dilihat dalam tabel 3 berikut ini: 
Tabel 3

Jumlah Persediaan di SC Wilayah Malang bulan Oktober 2004

\begin{tabular}{|c|c|c|c|c|c|c|}
\hline $\begin{array}{c}\text { Initial } \\
\text { Inventory }\end{array}$ & Tanggal & $\begin{array}{c}\text { Jml } \\
\text { pngrman } \\
\text { dr pabrik }\end{array}$ & $\begin{array}{c}\text { Jml } \\
\text { pngrman } \\
\text { ke outlet }\end{array}$ & $\begin{array}{l}\text { Safety } \\
\text { Stock }\end{array}$ & $\begin{array}{c}\text { Sediaan } \\
\text { akhir }\end{array}$ & $\begin{array}{c}\text { Biaya } \\
\text { Persediaan }\end{array}$ \\
\hline \multirow[t]{24}{*}{10023} & 4-Oct-04 & 3385 & 3352 & 10056 & 10056 & 241344 \\
\hline & 5-Oct-04 & 3548 & 3401 & 10203 & 10203 & 244872 \\
\hline & $6-O c t-04$ & 3321 & 3381 & 10143 & 10143 & 243432 \\
\hline & 7-Oct-04 & 3345 & 3372 & 10116 & 10116 & 242784 \\
\hline & 8-Oct-04 & 3292 & 3352 & 10056 & 10056 & 241344 \\
\hline & 9-Oct-04 & 3524 & 3395 & 10185 & 10185 & 244440 \\
\hline & 11-Oct-04 & 3327 & 3378 & 10134 & 10134 & 243216 \\
\hline & 12-Oct-04 & 2866 & 3250 & 9750 & 9750 & 234000 \\
\hline & 13-Oct-04 & 3802 & 3388 & 10164 & 10164 & 243936 \\
\hline & 14-Oct-04 & 3296 & 3365 & 10095 & 10095 & 242280 \\
\hline & $15-O c t-04$ & 3541 & 3409 & 10227 & 10227 & 245448 \\
\hline & 16-Oct-04 & 3341 & 3392 & 10176 & 10176 & 244224 \\
\hline & 18-Oct-04 & 3332 & 3377 & 10131 & 10131 & 243144 \\
\hline & 19-Oct-04 & 3485 & 3404 & 10212 & 10212 & 245088 \\
\hline & 20-Oct-04 & 3352 & 3391 & 10173 & 10173 & 244152 \\
\hline & 21-Oct-04 & 3323 & 3374 & 10122 & 10122 & 242928 \\
\hline & 22-Oct-04 & 3322 & 3361 & 10083 & 10083 & 241992 \\
\hline & 23-Oct-04 & 3293 & 3344 & 10032 & 10032 & 240768 \\
\hline & 25-Oct-04 & 3440 & 3368 & 10104 & 10104 & 242496 \\
\hline & 26-Oct-04 & 3504 & 3402 & 10206 & 10206 & 244944 \\
\hline & 27-Oct-04 & 3178 & 3346 & 10038 & 10038 & 240912 \\
\hline & 28-Oct-04 & 3582 & 3405 & 10215 & 10215 & 245160 \\
\hline & 29-Oct-04 & 3293 & 3377 & 10131 & 10131 & 243144 \\
\hline & 30-Oct-04 & 3345 & 3369 & 10107 & 10107 & 242568 \\
\hline & & & & & & 5.828 .616 \\
\hline
\end{tabular}

Dari tabel diatas dapat diketahui bahwa jumlah safety stock sesuai dengan kebijakan perusahaan yaitu sebesar tiga kali penjualan ( $3 \mathrm{x}$ potensi), dengan biaya persediaaan sebesar Rp. 5.828.616,-

Dengan penerapan crossdocking maka persediaan di sales center malang tidak lagi didasarkan pada tiga kali penjualan, tetapi didasarkan pada hasil perhitungan safety stock. Jumlah persediaan di sales Center Malang setelah diterapkannya crossdocking, dapat dilihat pada tabel 4 berikut : 
Tabel 4

Jumlah Persediaan usulan di SC Malang bulan Oktober 2004

\begin{tabular}{|c|c|c|c|c|c|c|}
\hline $\begin{array}{c}\text { Initial } \\
\text { Inventory }\end{array}$ & Tanggal & $\begin{array}{c}\text { Jml pngrman } \\
\text { dr pabrik }\end{array}$ & $\begin{array}{l}\text { Jml pngrman } \\
\text { ke outlet }\end{array}$ & $\begin{array}{l}\text { Safety } \\
\text { Stock }\end{array}$ & $\begin{array}{c}\text { Sediaan } \\
\text { akhir }\end{array}$ & $\begin{array}{c}\text { Biaya } \\
\text { persediaan (Rp) }\end{array}$ \\
\hline \multirow[t]{24}{*}{10023} & 4-Oct-04 & & 3352 & 593 & 6671 & 160104 \\
\hline & 5-Oct-04 & & 3401 & 593 & 3270 & 78480 \\
\hline & 6-Oct-04 & 704 & 3381 & 593 & 593 & 14232 \\
\hline & 7-Oct-04 & 3372 & 3372 & 593 & 593 & 14232 \\
\hline & 8-Oct-04 & 3352 & 3352 & 593 & 593 & 14232 \\
\hline & 9-Oct-04 & 3395 & 3395 & 593 & 593 & 14232 \\
\hline & $11-$ Oct-04 & 3378 & 3378 & 593 & 593 & 14232 \\
\hline & 12-Oct-04 & 3250 & 3250 & 593 & 593 & 14232 \\
\hline & $13-$ Oct-04 & 3388 & 3388 & 593 & 593 & 14232 \\
\hline & 14-Oct-04 & 3365 & 3365 & 593 & 593 & 14232 \\
\hline & $15-$ Oct-04 & 3409 & 3409 & 593 & 593 & 14232 \\
\hline & $16-$ Oct- 04 & 3392 & 3392 & 593 & 593 & 14232 \\
\hline & 18-Oct-04 & 3377 & 3377 & 593 & 593 & 14232 \\
\hline & 19-Oct-04 & 3404 & 3404 & 593 & 593 & 14232 \\
\hline & 20-Oct-04 & 3391 & 3391 & 593 & 593 & 14232 \\
\hline & 21-Oct-04 & 3374 & 3374 & 593 & 593 & 14232 \\
\hline & 22-Oct-04 & 3361 & 3361 & 593 & 593 & 14232 \\
\hline & 23-Oct-04 & 3344 & 3344 & 593 & 593 & 14232 \\
\hline & 25-Oct-04 & 3368 & 3368 & 593 & 593 & 14232 \\
\hline & 26-Oct-04 & 3402 & 3402 & 593 & 593 & 14232 \\
\hline & 27-Oct-04 & 3346 & 3346 & 593 & 593 & 14232 \\
\hline & 28-Oct-04 & 3405 & 3405 & 593 & 593 & 14232 \\
\hline & 29-Oct-04 & 3377 & 3377 & 593 & 593 & 14232 \\
\hline & 30-Oct-04 & 3369 & 3369 & 593 & 593 & 14232 \\
\hline & & & & & & $\mathbf{5 5 1 . 6 8 8}$ \\
\hline
\end{tabular}

* Dari tabel diatas maka jumlah persediaan di Sales Center malang tidak lagi didasarkan dari tiga kali penjualan tetapi didasarkan dari perhitungan safety stock. Maka jumlah persediaan menurun dari tiga kali penjualan menjadi 593 krat. Biaya persediaan menurun dari Rp. 5.828.616,00 menjadi Rp.551.688,00

\section{Biaya Transportasi}

Besarnya biaya transportasi sesuai dengan kebijakan perusahaan yaitu sebesar Rp.258,-/krat untuk botol full. Besarnya biaya transportasi sebelum dan sesudah diterapkannya crossdocking dapat dilihat pada tabel 5 berikut ini : 
Tabel 5

Biaya transportasi sebelum dan sesudah diterapkan crossdocking bulan Oktober2004

\begin{tabular}{|c|c|c|c|c|c|c|c|c|}
\hline \multirow[b]{2}{*}{ Tanggal } & \multicolumn{4}{|c|}{$\begin{array}{c}\text { Sebelum } \\
\text { crossdocking }\end{array}$} & \multicolumn{4}{|c|}{$\begin{array}{c}\text { Sesudah } \\
\text { crossdocking }\end{array}$} \\
\hline & $\begin{array}{c}\text { Jml } \\
\text { pngrman } \\
\text { dr pabrik }\end{array}$ & $\begin{array}{c}\text { Jml } \\
\text { pngrman } \\
\text { ke outlet }\end{array}$ & $\begin{array}{c}\text { Biaya } \\
\text { transport } \\
\text { dr pabrik }\end{array}$ & $\begin{array}{c}\text { Biaya } \\
\text { transport } \\
\text { ke outlet }\end{array}$ & $\begin{array}{c}\text { Jml } \\
\text { pngrman } \\
\text { dr pabrik }\end{array}$ & $\begin{array}{c}\text { Jml } \\
\text { pngrman } \\
\text { ke outlet }\end{array}$ & $\begin{array}{c}\text { Biaya } \\
\text { transport } \\
\text { dr pabrik }\end{array}$ & $\begin{array}{c}\text { Biaya } \\
\text { transport } \\
\text { ke outlet }\end{array}$ \\
\hline 4-Oct-04 & 3385 & 3352 & 873330 & 864816 & & 3352 & & 864816 \\
\hline 5-Oct-04 & 3548 & 3401 & 915384 & 877458 & & 3401 & & 877458 \\
\hline $6-O c t-04$ & 3321 & 3381 & 856818 & 872298 & 704 & 3381 & 181632 & 872298 \\
\hline 7-Oct-04 & 3345 & 3372 & 863010 & 869976 & 3372 & 3372 & 869976 & 869976 \\
\hline 8-Oct-04 & 3292 & 3352 & 849336 & 864816 & 3352 & 3352 & 864816 & 864816 \\
\hline 9-Oct-04 & 3524 & 3395 & 909192 & 875910 & 3395 & 3395 & 875910 & 875910 \\
\hline 11-Oct-04 & 3327 & 3378 & 858366 & 871524 & 3378 & 3378 & 871524 & 871524 \\
\hline 12-Oct-04 & 2866 & 3250 & 739428 & 838500 & 3250 & 3250 & 838500 & 838500 \\
\hline 13-Oct-04 & 3802 & 3388 & 980916 & 874104 & 3388 & 3388 & 874104 & 874104 \\
\hline 14-Oct-04 & 3296 & 3365 & 850368 & 868170 & 3365 & 3365 & 868170 & 868170 \\
\hline 15-Oct-04 & 3541 & 3409 & 913578 & 879522 & 3409 & 3409 & 879522 & 879522 \\
\hline 16-Oct-04 & 3341 & 3392 & 861978 & 875136 & 3392 & 3392 & 875136 & 875136 \\
\hline 18-Oct-04 & 3332 & 3377 & 859656 & 871266 & 3377 & 3377 & 871266 & 871266 \\
\hline 19-Oct-04 & 3485 & 3404 & 899130 & 878232 & 3404 & 3404 & 878232 & 878232 \\
\hline 20-Oct-04 & 3352 & 3391 & 864816 & 874878 & 3391 & 3391 & 874878 & 874878 \\
\hline 21-Oct-04 & 3323 & 3374 & 857334 & 870492 & 3374 & 3374 & 870492 & 870492 \\
\hline 22-Oct-04 & 3322 & 3361 & 857076 & 867138 & 3361 & 3361 & 867138 & 867138 \\
\hline 23-Oct-04 & 3293 & 3344 & 849594 & 862752 & 3344 & 3344 & 862752 & 862752 \\
\hline 25-Oct-04 & 3440 & 3368 & 887520 & 868944 & 3368 & 3368 & 868944 & 868944 \\
\hline 26-Oct-04 & 3504 & 3402 & 904032 & 877716 & 3402 & 3402 & 877716 & 877716 \\
\hline 27-Oct-04 & 3178 & 3346 & 819924 & 863268 & 3346 & 3346 & 863268 & 863268 \\
\hline 28-Oct-04 & 3582 & 3405 & 924156 & 878490 & 3405 & 3405 & 878490 & 878490 \\
\hline 29-Oct-04 & 3293 & 3377 & 849594 & 871266 & 3377 & 3377 & 871266 & 871266 \\
\hline 30-Oct-04 & 3345 & 3369 & 863010 & 869202 & 3369 & 3369 & 869202 & 869202 \\
\hline & & & 20907546 & 20885874 & & & 18452934 & 20885874 \\
\hline
\end{tabular}

Dari tabel 5 terlihat bahwa biaya menghindari terjadinya lost sale.Sedangkan biaya transportasi dari pabrik ke sales center mengalami transportasi ke outlet tidak mengalami perubahan penurunan, hal ini disebabkan karena jumlah atau sama hal ini disebabkan jumlah pengiriman pengiriman produk yang berbeda, dimana sebelum produk sama.

diterapkan crossdocking perusahaan memakai kebijakan bahwa persediaan tiga ka-i penjualan

\section{Penjadwalan Produk dari Pabrik ke Outlet} maka pengiriman produk akan semakin besar, sebaliknya dengan diterapkan crossdocking pengiriman produk sesuai dengan jumlah konsep crossdocking ini diterapkan dengan menjadwalkan pengiriman produk dari pabrik penjualan, tetapi tatap ada safety stock untuk hingga ke outlet melalui Sales Center. 
Penjadwalan pengiriman dilakukan melalui 2 David Shimchi Levi, Philips Kaminsky, Edith tahapan:

1.Penjadwalan dari pabrik ke Sales Center

2. Penjadwalan produk dari Sales Center ke outlet

\section{E. KESIMPULAN}

Berdasarkan hasil pembahasan sebelumnya dan mengacu pada tujuan yang telah ditetapkan pada awal penelitian, kesimpulan yang dapat diambil adalah sebagai berikut:

1. Dengan penghitungan safety stock maka persediaan di sales center malang tidak didasarkan pada tiga kali permintaan/penjualan tetapi didasarkan pada hasil perhitungan safety stock. Penurunan tingkat persediaan produk dari tiga kali permintaan/penjualan menjadi 593 krat.

2. Terjadi penurunan biaya simpan dari Rp. 5.828.616,00 menjadi Rp.551.688,00

Artinya perusahaan mampu menurunkan biaya sebesar Rp. 5.276.928,00

3. Biaya transportasi dari pabrik ke sales center mengalami penurunan dari Rp. 20.907.546,00 menjadi Rp. 18.452.934,00, Artinya perusahaan mampu menurunkan biaya transport sebesar $\quad$ Rp. 2.454.612,00

\section{DAFTAR PUSTAKA}

Ballow, Ronald H ; Busines Logistics Management Planning Organizing and Controller The Supply Chain, $4^{\text {th }}$ edition, Prentice Hall ; 1992
Schimci Levi ; Designing and Menaging The Supply Chain ; Concept, Strategies, and Case Studies Singapore; Mc Graw Hill ; Inc 2000

Arman Hakim Nasution, Perencanaan dan Pengendalian Poduksi edisi I, Guna Widya Surabaya, 2003

Miranda, ST Drs Amin Jijaya Tunggal Ab,MBA; Menejemen Logitik dan Supply Chain managemant ; Harvarindo Jakarta 2003

Teguh Baroto ST, Perencanaan dan Pengendalian Produksi, Ghalia Indonesia 2002

Richard J Tersine, Principles Of Inventory and Material Management, North Holland 1983

Indra Destriyana; Perencanaan Sistem Distribusi dengan Metode Crossdocking, Jurusan Teknik Indutri, Fakultas Teknologi Industri, Institut Teknologi Sepuluh November Surabaya, 2002 